\title{
Growth Analysis of Baby Corn (Zea mays L.) Under the Effect of Integrated Nutrient Management
}

\author{
Garima Joshi ${ }^{1}$, M. S. Pal ${ }^{2}$ and Aaradhana Chilwal ${ }^{3 *}$ \\ 1\&2GBPUAT, Pantnagar (Uttarakhand), email- garimajoshi007@g mail.com \\ 2*PAU, Ludhiana (Punjab), email- acaaradhana@gmail.com \\ *corresponding author
}

\begin{abstract}
Maize (Zea mays L.) is the most versatile crop having wider adaptability in varied ecologies. Presently baby corn is gaining popularity among Indian farming communities mainly due to its short duration, high market rate, nutritive value and also its multiuse. Baby corn requires higherpopulation and plant nutrition than normal grain corn. Therefore the nutrient management is of immense importance for higher corn production. The present study was thus carried out during Kharif season 2015 at the Instructional Dairy Farm (IDF), Nagla, Govind Ballabh Pant University of Agriculture and Technology, Pantnagar, Uttarakhand to analyse the growth of baby corn under the effect of integrated nutrient management. The experimental design was Randomized Block Design with 11 treatments consisting of sole application of NPK fertilizer, sole application of Azotobacter and Azospirillum, and application of Azotobacter and Azospirillum along with NPK fertilizer. The study revealed that Leaf area index was significantly higher at 50 DAS and harvest under $100 \%$ NPK+Azot+Azos. Application of $75 \%$ NPK + Azot + Azos had significantly higher $\overline{C G R}$ at 25-50 DAS while 100\% $N P K+$ Azot+Azos gave significantly higher $\overline{C G R}$ at 50 $D A S$ - harvest. The $\overline{R G R}$ values remained non significant at both the stages, however the highest $\overline{R G R}$ was recorded at application of $100 \%$ NPK+Azot+Azos. The $\overline{N A R}$ remained non significant at $25-50$ DAS but at 50 $D A S$ - harvest, the $\overline{N A R}$ values recorded significantly higher at $100 \% \quad N P K+$ Azot + Azos that remained non significant with all the treatments except control and seed treatment with Azotobacter. The $\overline{L A R}$ too was recorded non significant by different integrated nutrient management practices at 25-50 DAS but at 50 DAS-harvest, the significantly highest $\overline{L A R}$ was recorded under control, whereas the lowest $\overline{L A R}$ was found at application of
\end{abstract}

$100 \%$ NPK that remained statistically at par with all other treatments except control. Higher dose of nitrogen coupled with biofertilizers improved the plant growth.

Keywords- azotobacter, azospirillum, leaf area index, crop growth rate, relative growth rate, net assimilation rate, leaf area ratio.

\section{INTRODUCTION}

Maize is the third most important staple food crop in the world after wheat and rice but in term of productivity, it ranks first followed by rice, wheat and other millets. Presently baby corn is gaining popularity among Indian farming communities mainly due to its short duration, high market rate, nutritive value and also its multiuse. Baby corn is dehusked immature maize ear, harvested within 2-3 days of silking but prior to fertilization (Pandey et al., 1998). Baby corn is used as vegetable, salad, soup, pickle, kheer, murabba, chutney, manchurian, halwa etc. Baby corn is highly nutritive as $100 \mathrm{~g}$ of baby corn contains $89.1 \%$ moisture, $0.2 \mathrm{~g}$ fat, $1.9 \mathrm{~g}$ protein, $8.2 \mathrm{mg}$ carbohydrate, 0.06 $\mathrm{g}$ ash, $28.0 \mathrm{mg}$ calcium, $86.0 \mathrm{mg}$ phosphorus, $11.0 \mathrm{mg}$ ascorbic acid (Das et al., 2009). Baby corn has a great potential to fetch foreign currency through international trade. There is a great demand of baby corn in international market mainly because of its freshness, taste, nutrition, free from pesticides and its multiuse.

In general, morphology, physiology and agronomy of baby corn differed from grain corn as the varieties grown for baby corn must have high vigour and prolificacy. It responds to higher doses of fertilizer that may normally cause lodging in other cereal crops. Thus nutrient management is a very important aspect for proper growth of baby corn. The leaf area, LAI and dry accumulation per plant was noticed significantly higher at application of 240 $\mathrm{kg} \mathrm{N} \mathrm{ha-1} \mathrm{over} 0,60,120$ and $180 \mathrm{~kg} \mathrm{ha}^{-1} \mathrm{~N}$ (Kaledhonkar, 2003). Verma et al. (2006) also found that 
150 per cent recommended NPK gave the maximum plant height, leaf area index of maize. Kumar et al. (2007) noticed that leaf area index and total dry matter production of sweet corn were influenced favourably with increasing levels of $\mathrm{N}, \mathrm{P}_{2} \mathrm{O}_{5}$ and $\mathrm{K}_{2} \mathrm{O}$ up to $150: 60: 40 \mathrm{~kg} \mathrm{ha}^{-1}$, respectively. Suryavanshi et al. (2008) reported that $150 \mathrm{~kg}$ $\mathrm{N}$ gave higher leaf area index (LAI) and dry matter production of maize compared to either 50 or $100 \mathrm{~kg} \mathrm{~N} \mathrm{ha}^{-1}$. Chemical fertilizers may solve the problem but organics are required to minimize the harmful effects of chemicals. Higher leaf area index was observed in different crops when inoculation was done with Pseudomonas, Azospirillum and Azotobacter strains (Siddiqui and Shaukat, 2002). Prasad et al. (2003) reported that application of $5 \mathrm{t} \mathrm{ha}^{-1}$ vermicompost along with 14 and $10 \mathrm{t} \mathrm{ha}^{-1}$ poultry manure and FYM gave higher leaf area index. Jayaprakash $\boldsymbol{e t}$ al. (2004) studied the effect of organics on maize and found that application of vermicompost @ $2 \mathrm{t} \mathrm{ha}^{-1}$ and FYM @ 10 t ha ${ }^{-1}$ resulted in significantly higher LAI compared to no organics. Best way out is integration of chemicals and organics. The combination of FYM and mineral fertilizer significantly increased the leaf number and leaf area index of maize (Haq, 2006). Gable et al. (2008) reported significantly higher all growth parameters of maize were at application of $100 \%$ recommended dose of fertilizer (225:50:50 kg NPK ha-1) followed by $75 \% \mathrm{RDF}+25 \% \mathrm{~N}$ through Leucaena lopping + biofertilizer. Panwar (2008) observed that integrated nutrient management had significant effect on growth parameters of maize crop. Megawer and Mahfouz (2010) reported that inoculation of canola seeds by either Azotobacter, Azospirillum or the mixed inoculum and adding half recommended dose of nitrogen showed high leaf area and save half of the mineral nitrogen recommended dose. Thus the present study was carried out to find out the best integrated nutrient management practice for baby corn under which the crop would show best results in terms of growth.

\section{MATERIAL AND METHODS}

The experiment was conducted at the Instructional Dairy Farm (IDF), Nagla, Govind Ballabh Pant University of Agriculture and Technology, Pantnagar, Udham Singh Nagar, Uttarakhand, India. The Instructional Dairy Farm is located in the Tarai belt of Shivalik range of Himalayas with humid sub-tropical type of climate at latitude of $29^{\circ} \mathrm{N}$ and longitude of $79.3^{\circ} \mathrm{E}$ and situated at an altitude of 243.84 $\mathrm{m}$ above the mean sea level. The climate of the Tarai region is broadly humid sub-tropical with harsh winter and hot dry summers. The soil of the experimental field was slightly silty clay loam (Nagla series, Mollisol) in texture, from dark greyish brown to dark grey in humus with weak, fine to medium granular structure.

Eleven treatments were tested in a Randomized Block Design 3 replications the treatments were Control (no application), 50\% NPK, 100\% NPK(180:60:40), Seed treatment with Azotobacter @200g/10Kg seeds, Seed treatment with Azospirillum @200g/10Kg seeds, Seed treatment with Azospirillum + Azotobacter, 50\% NPK + Seed treatment with Azotobacter, 50\% NPK + Seed treatment with Azospirillum, 50\% NPK+ Seed treatment with Azospirillum + Azotobacter, 50\% NPK+ Seed treatment with Azospirillum + Azotobacter and $100 \% \mathrm{NPK}+$ seed treatment with Azospirillum + Azotobacter. The variety sown was V.L. Baby corn-1 released from Vivekananda Parvatiya Krishi Anusandhan Sansthan, Almora,Uttarakhand.

\section{RESULTS AND DISCUSSION Leaf Area Index (LAI)}

The LAI remained non significant under different integrated nutrient management practices at 25 DAS. At 50 DAS and harvest, significantly higher LAI was recorded with application of $100 \% \mathrm{NPK}+$ Azot + Azos that remained at par with $100 \%$ NPK, 50\% NPK+Azot+Azos and 75\% $\mathrm{NPK}+$ Azot + Azos at $50 \mathrm{DAS}$ and with $100 \% \mathrm{NPK}$ and $75 \%$ $\mathrm{NPK}+$ Azot + Azos at harvest stage. Among the biofertilizer treatments, the LAI at 50 DAS remained non significant, however combined seed treatment produced the higher LAI followed by seed treatment with Azotobacter. At harvest, seed treatment with Azot+Azos produced significantly highest LAI than seed treated with either of biofertilizers. Nitrogen is the main constituent of chlorophyll that keeps leaf greener for longer period and also improved photosynthesis that finally resulted into better leaf growth and development. The data pertaining to LAI is given in table 1.

\section{Mean Crop Growth Rate $(\overline{C G R})$}

At $25-50$ DAS, the highest ( $\overline{C G R}$ ) was recorded with application of $75 \% \mathrm{NPK}+$ Azot + Azos that remained significantly at par with application of $100 \%$ NPK, $50 \%$ $\mathrm{NPK}+$ Azot + Azos and $100 \% \mathrm{NPK}+$ Azot + Azos, whereas at 50 DAS - harvest, the higher ( $\overline{C G R}$ ) values were recorded with application of $100 \%$ NPK + Azot + Azos that was significantly similar to $100 \%$ NPK, $50 \% \mathrm{NPK}+$ Azot, $50 \%$ $\mathrm{NPK}+$ Azot + Azos and $75 \% \mathrm{NPK}+$ Azot + Azos. Among the biofertilizer treatments, the $(\overline{C G R})$ at 25-50 DAS and 50 DAS-harvest remained non significant with each other, however combined seed treatment recorded higher $(\overline{C G R})$ at both the stages followed by seed treatment with 
Azotobacter. The lowest $(\overline{C G R})$ was recorded under control at both the stages. The higher $(\overline{C G R})$ value might be caused due to better plant growth at combined application of nitrogen and bioferilizers.

\section{Relative Growth Rate $(\overline{R G R})$}

The data pertaining to $(\overline{R G R})$ indicated that it declined with advancement of crop age. The highest and the lowest $(\overline{R G R})$ values were recorded with application of $100 \% \mathrm{NPK}+$ Azot + Azos and under control at both $25-50$ DAS and at 50 DAS - harvest crop stages, respectively. Among the biofertilizer treatments, the highest $(\overline{R G R})$ values were recorded at seeds treated with Azotobacter+Azospirillum followed by seed treatment with Azotobacter. Similarly, at 25-50 DAS, 50\% $\mathrm{NPK}+A z o t+A z o s$ recorded the highest $(\overline{R G R})$ value followed by $50 \% \mathrm{NPK}+$ Azot. At 50 DAS - harvest stage the highest $(\overline{R G R})$ value was recorded at $50 \% \mathrm{NPK}+A z$ ot followed by $50 \% \mathrm{NPK}+$ Azot + Azos. The data pertaining to CGR and RGR is given in table 2.

\section{Net Assimilation Rate $(\overline{N A R})$}

The net assimilation rate was recorded non significant by different integrated nutrient management practices at 25-50 DAS. At 50 DAS-harvest, significantly higher $(\overline{N A R})$ value was recorded with application of $100 \%$ NPK+Azot + Azos that remained statistically at par with all the treatments except control and seed treatment with Azospirillum. The $(\overline{N A R})$ was recorded non significant among the treatments where either alone or combined biofertilizers were used for seed treatment, but combined seed treatment with biofertilizer and seed treatment with Azotobacter produced the highest $(\overline{N A R})$ followed by seed treatment with Azospirillum. The ( $\overline{N A R}$ ) was recorded significantly lower with alone application of $50 \%$ NPK than all treatments having 50\% NPK+ seed treatments with biofertilizers.

\section{Leaf Area Ratio ( $\overline{L A R}$ )}

The leaf area ratio was recorded non significant by different integrated nutrient management practices at 25-50 DAS. At 50 DAS-harvest, the significantly highest $(\overline{L A R})$ was recorded under control, whereas the lowest $(\overline{L A R})$ was found with application of $100 \%$ NPK that remained statistically at par with all other treatments except control. Among the biofertilizers treatments, $(\overline{L A R})$ remained non significant, however seed treatment with Azospirillum recorded the highest ( $\overline{L A R}$ ) followed by seed treatment with Azot+Azos. The LAR remained non significant among the treatments having combined application of $50 \%$ NPK + biofertilizers, but the highest ( $\overline{L A R}$ ) was noticed with application of $50 \%$ NPK+Azos followed by $50 \%$ $\mathrm{NPK}+$ Azot. The data pertaining to NAR and LAR is given in table 3 .

\section{Conclusion}

Combined application of nitrogen and bioferilizers improved photosynthesis that finally resulted into better leaf growth and crop growth. The present study concluded the benefits of integrated nutrient management including use of biofertilizers in combination of chemical fertilizers and its positive effect on growth of baby corn.

Table.1: Effect of integrated nutrient management on leaf area index at different growth stages of baby corn

\begin{tabular}{|c|c|c|c|}
\hline \multirow[b]{2}{*}{ Treatment } & \multicolumn{3}{|c|}{ Leaf Area Index } \\
\hline & 25 DAS & 50 DAS & Harvest \\
\hline Control & 0.14 & 2.50 & 3.07 \\
\hline Azotobacter & 0.17 & 2.80 & 3.37 \\
\hline Azospirillum & 0.16 & 2.70 & 3.23 \\
\hline Azot + Azos & 0.17 & 3.00 & 3.77 \\
\hline $50 \%$ NPK & 0.18 & 3.20 & 3.80 \\
\hline $100 \%$ NPK & 0.21 & 4.00 & 4.47 \\
\hline $50 \%$ NPK + Azotobacter & 0.19 & 3.60 & 4.20 \\
\hline 50\% NPK +Azospirillum & 0.18 & 3.50 & 3.93 \\
\hline $50 \%$ NPK $+A z o t+A z o s$ & 0.2 & 3.70 & 4.27 \\
\hline $75 \%$ NPK + Azot $+A z o s$ & 0.22 & 4.20 & 4.60 \\
\hline $100 \%$ NPK + Azot $+A z o s$ & 0.21 & 4.30 & 4.67 \\
\hline SEm \pm & 0.08 & 0.23 & 0.09 \\
\hline $\operatorname{LSD}(\mathrm{p}=\mathbf{0 . 0 5})$ & $\mathrm{ns}$ & 0.68 & 0.28 \\
\hline
\end{tabular}


Table.2: Effect of integrated nutrient management on crop growth rate and relative growth rate at different growth stages of baby corn

\begin{tabular}{|c|c|c|c|c|}
\hline \multirow[b]{2}{*}{ Treatment } & \multicolumn{2}{|c|}{$(\overline{C G R})\left(\mathrm{g} / \mathrm{m}^{2} / \mathrm{day}\right)$} & \multicolumn{2}{|c|}{$(\overline{R G R})(\mathrm{mg} / \mathrm{g} / \mathrm{day})$} \\
\hline & 25-50 DAS & 50 DAS-harvest & 25-50 DAS & 50 DAS-harvest \\
\hline Control & 2.81 & 2.44 & 60.10 & 23.90 \\
\hline Azotobacter & 4.02 & 4.30 & 62.16 & 29.35 \\
\hline Azospirillum & 3.82 & 3.93 & 61.67 & 28.10 \\
\hline Azot $+A z o s$ & 4.12 & 4.52 & 62.63 & 29.88 \\
\hline $50 \%$ NPK & 4.43 & 5.00 & 62.92 & 30.70 \\
\hline $100 \%$ NPK & 5.41 & 6.96 & 64.35 & 34.63 \\
\hline $50 \%$ NPK + Azotobacter & 4.87 & 6.15 & 63.95 & 33.76 \\
\hline $50 \%$ NPK +Azospirillum & 4.52 & 5.48 & 63.19 & 32.59 \\
\hline $50 \% \mathrm{NPK}+A z o t+A z o s$ & 5.07 & 6.37 & 64.13 & 33.67 \\
\hline $75 \%$ NPK + Azot + Azos & 5.51 & 7.30 & 64.56 & 35.35 \\
\hline $100 \% \mathrm{NPK}+A z o t+A z o s$ & 5.47 & 7.67 & 64.75 & 37.14 \\
\hline SEm \pm & 0.20 & 0.55 & 1.62 & 3.33 \\
\hline LSD $(p=0.05)$ & 0.61 & 1.63 & Ns & Ns \\
\hline
\end{tabular}

Table.3: Effect of integrated nutrient management on net assimilation rate and leaf area rate at different growth stages of baby

corn

\begin{tabular}{|c|c|c|c|c|}
\hline \multirow[t]{2}{*}{ Treatment } & \multicolumn{2}{|c|}{$(\overline{N A R})\left(\mathbf{m g} / \mathrm{cm}^{2} /\right.$ day $)$} & \multicolumn{2}{|c|}{$(\overline{L A R})\left(\mathrm{cm}^{2} / \mathrm{g}\right)$} \\
\hline & 25-50 DAS & $\begin{array}{l}\text { 50 DAS- } \\
\text { harvest }\end{array}$ & 25-50 DAS & 50 DAS-harvest \\
\hline Control & 0.35 & 0.06 & 175.6 & 372.8 \\
\hline Azotobacter & 0.42 & 0.11 & 146.4 & 276.3 \\
\hline Azospirillum & 0.42 & 0.10 & 146.2 & 285.2 \\
\hline$A z o t+A z o s$ & 0.42 & 0.11 & 150.1 & 278.7 \\
\hline $50 \%$ NPK & 0.42 & 0.11 & 152.0 & 279.8 \\
\hline $100 \%$ NPK & 0.43 & 0.14 & 152.6 & 251.2 \\
\hline $50 \%$ NPK + Azotobacter & 0.42 & 0.13 & 153.6 & 266.0 \\
\hline $50 \%$ NPK + Azospirillum & 0.40 & 0.12 & 156.2 & 281.4 \\
\hline $50 \% \mathrm{NPK}+A z o t+A z o s$ & 0.42 & 0.13 & 153.4 & 260.2 \\
\hline $75 \%$ NPK + Azot $+A z o s$ & 0.40 & 0.14 & 161.0 & 258.6 \\
\hline $100 \% \mathrm{NPK}+A z o t+A z o s$ & 0.41 & 0.15 & 158.6 & 255.6 \\
\hline SEm \pm & 0.22 & 0.02 & 7.1 & 12.0 \\
\hline LSD $(p=0.05)$ & Ns & 0.04 & Ns & 35.7 \\
\hline
\end{tabular}

\section{ACKNOWLEDGEMENT}

Support from Dr Dr. M.S. Pal, Professor, Department of Agronomy, College of Agriculture, GBPUAT, Pantnagar is gratefully acknowledged.

\section{REFERENCES}

[1] Das, S., Ghosh, G., Kaleem, M.D. and Bahadur, V. (2009). Effect of different levels of nitrogen and crop geometry on the growth, yield and quality of babycorn
(Zea mays L.) cv. 'golden baby'. Acta Horti. 809: 161166

[2] Gable, D.B., Kubde, K.J., Katore, J.R., Fiske, A.V. and Deshmukh, M.R. (2008). Effect of integrated nutrient management on growth and yield of maizechickpea cropping system. J. of Soils and Crops. 18(2): 392-397.

[3] Haq, S.A. (2006). Integrated Nutrient Management in maize (Zea mays L.) under irrigated agro-ecosystem of Kashmir Valley. M.Sc. Research Thesis. p.120. 
[4] Jayaprakash, D.C., Sawant, P.S. and Singh, R.S. (2004). Effect of vermicompost on growth and yield of maize as well as nutrient uptake. Indian J. Agron. 23(1): 121-123.

[5] Kaledhonkar, P.R. (2003). Evaluation of promising quality protein maize (Zea mays) cultivars in Konkan region. Thesis, M. Sc. Agriculture Dr. Balasaheb Sawant Konkan Krishi Vidyapeeth, Dapoli, Dist. Ratnagiri. 72p.

[6] Kumar, A.M.A., Gali, S.K. and Hebsur, N.S. (2007). Effect of different levels of NPK on growth and yield parameters of sweet corn. Karnataka J. Agric. Sci. 20(1): 41- 43.

[7] Megawer, E. A. and S. A. Mahfouz. (2010). Response of canola (Brassica napus L.) to bio-fertilizers under Egyptian conditions in newly reclaimed soil. International J. Agric. Sci. 2(1): 12-17.

[8] Pandey, A.K., Prasad, Kamta, Mani, V.P., Chauhan, V.S. and Singh, Prem. (1998). Improved maize production technology for mid-hills of N-W Himalayas. Technical Bulletin 11: 1-46.

[9] Panwar, A.S. (2008). Effect of Integrated Nutrient Management in maize (Zea mays)- mustard (Brassica compestris var toria) cropping system in mid hills altitude. Indian J. Agric. Sci. 78(1): 27-31.

[10] Prasad, B.K., Singh, D.N. and Singh, S. N. (2003). Effect of long-term use on fertilizer, lime and manures on growth and yield of sweet corn. J. Indian Soc. Soil Sci. 34: 271-274.

[11] Siddiqui, I.A. and S.S. Shaukat. (2002). Mixtures of plant disease suppressive bacteria enhance biological uptake control of multiple tomato pathogens. Biology and Fertility of Soil. 36(4): 284-297.

[12] Suryavanshi, V.P., Chavan, B.N., Jadhav, V.T. and Baig, M.I.A. (2008). Response of maize to nitrogen and phosphorous application in Vertisols. International J. Tropical Agric. 26: 293-296.

[13] Verma, A., Nepalia, V. and Kanthaliya, P.C. (2006). Effect of integrated nutrient supply on growth, yield and nutrient uptake by maize (Zea mays L)-wheat (Triticum aestivum) cropping system. Indian J. Agron. 51(1): $3-6$ 